\title{
Proceeding
}

6th INSHS International Christmas Sport Scientific Conference, 11-14 December 2011. International Network of Sport and

Health Science. Szombathely, Hungary

\section{The influence of football on the personal development of children in Uganda}

\author{
SIMONA ŠAFAŘíKOVÁ \\ Department of Social Sciences in Kinantropology, Faculty of Physical Culture, Palacky University, Olomouc, Czech \\ Republic
}

\begin{abstract}
Šafaríková S. The influence of football on the personal development of children in Uganda. J. Hum. Sport Exerc. Vol. 7, No. Proc1, pp. S173-S177, 2012. This article provides information on an ongoing research in the field of Sport and Development. The aim of the whole research is to provide knowledge on the role of the football in the personal development of children in the context of developing countries. The sample analysed in this article includes semi-structured interviews with three youth players from the Kids League in Uganda. The researcher also used other methods during this study. All three interviews were carried out during the Football for Hope Festival in South Africa in 2010. Only the results of these interviews are presented in this article. These findings are seeing football very positively. The youth consider football as very important. It enables them to meet new people, learn new skills and some of them want to build their professional career. Key words: SPORT AND DEVELOPMENT, DEVELOPING COUNTRIES, THE KIDS LEAGUE.
\end{abstract}

Corresponding author. Tř. Míru 115, Olomouc, 771 11, Czech Republic.

E-mail: simona.safarikova@upol.cz

6th INSHS International Christmas Sport Scientific Conference, 11-14 December 2011. International Network of Sport and Health Science. Szombathely, Hungary

JOURNAL OF HUMAN SPORT \& EXERCISE ISSN 1988-5202

(c) Faculty of Education. University of Alicante

doi:10.4100/jhse.2012.7.Proc1.19 


\section{INTRODUCTION}

Nowadays sport and physical activities are being used as tool in many programs of development cooperation in the developing countries (Levermore \& Beacom, 2009). Sport is said to be a very useful instrument when fighting poverty and achieving the Millenium Development Goals (MDGs). Since several years the academic community has been trying to foster the research in this area of "sport and development". The research is being spread and the evaluation of different programs is being provided (Levermore, 2011) especially in the last five years. There are also very critical thoughts within the academic community that analyze the practices used within the development cooperation and in the development community. These voices criticize the whole concept of "Sport and Development" as a new neoliberal way of exercising the power relations in today's world (Hayhurst, 2009; Darnell, 2007). Other voices from the field (Nicholls, 2011) address the lack of discussion among the practitioners, academics and policy makers. Nicholls (2011) argues that the local practitioners' knowledge is not taken into consideration within the academic research and therefore she calls for bigger integration of local knowledge into the research.

The presented research is aimed on the role of sport in the development of the children within the context of developing countries. The focus of the proposed article is made on several youth participants of the Kids League Uganda. The Kids League is one of the organizations that works in this field and provides the sporting possibilities and activities for the Ugandan youth. The researcher focused on the influence of football on the personal development of the children who have been taking part in the football programs. This article presents only the analysis of one of the methods (semi-structured interviews) used in the whole study.

The personal development is here defined as the positive changes in the structure of the system of mental processes, conditions and characteristics (Kohoutek, 2000; Smékal, 2004) originating in socialization and restructuring of inherent qualities. The personal development therefore is a process that contributes to the improvement of the individual's identity, develops his/her talents and abilities and therefore betters the quality of life. Through the personal development the individual is empowered to realize the personal dreams and aspirations (Aubrey, 2010). Sport is said to have the potential to contribute to this personal development. It depends very much on the way if its use in practice. This article describes the role of football programs and how the youth perceives its influence on their lives.

\section{MATERIAL AND METHODS}

The aim of the researcher was to give the space to the children who have been taking part in the football programs and bring into the academic research their voices. The whole research is a qualitative based study that uses the case study design as mentioned in Hendl (2008). Within the case study there were different methods applied - observation, semi-structured interviews and focus group (Punch, 2005). The participants of this research are people who are in some ways involved (or are in touch with) in the activities of The Kids League (TKL) (Uganda) and The Search and Groom (Nigeria) - mainly youth who takes part in the regular football trainings and activities and furthermore their parents, coaches and teachers - people who are in very close touch with them. 
As already mentioned, the presented research focuses on the role of sport in the development of the children within the context of developing countries. Therefore the research questions are shaped in the following way. What does the experience from international football tournament bring into the personal development of each individual? What does football itself bring into the personal development of each individual? How it is possible to transfer the football experience into the everyday life?

For this article an analysis of three randomly selected semi-structured interviews with the Ugandan youth were selected (boys - 17, 17 and 18 years). All three teenagers participated at the Football for Hope Festival in South Africa in 2010. This football festival was an official part of the World Cup and it was coorganized by FIFA and streetfootballworld. There were 32 different organizations (NGOs) taking part in this festival. All these NGOs use football as a tool for further development of children. They organize regular trainings, activities and events during the whole year. Generally they also take their participants for the tournaments abroad. The Football for Hope Festival lasted for 2 weeks and the youth had the possibility to get to know each other during the $1^{\text {st }}$ week and then play the football tournament according to the fair play rules during the $2^{\text {nd }}$ week of their stay in South Africa. The semi-structured interviews were taken during this event. For each interview the same set of questions was used and enriched by others that were coming out during the internship. Each interview took about 15-20 minutes. All the 3 firstly selected interviews were transcribed and analyzed progressively. The first results for this article were achieved through categorizing and constant comparative method. The categories came out of the data instead of imposing them at the beginning. However it is necessary to make clear that the results presented here are not the final ones and therefore the researcher will continue with the analysis of all other data and methods gradually. All the participants of the interviews were informed about the aims of the research and agreed on its anonymity and confidentiality.

\section{RESULTS}

Results presented here are coming from the analysis of first three interviews. This analysis and the experience gained through it will be used in further work of the researcher. Through the constant comparative analysis the following categorical issues emerged from these first interviews - festival importance and mood; exposure, education and discipline; connection to the situation in Uganda.

\section{Festival importance and festival mood}

All the participants mentioned that they got sick during the festival and it was disturbing for them. At the beginning of the festival it brought bad mood into the team. It was colder in South Africa then in Uganda and these participants experienced this weather conditions for the first time. They were mentioning that this tournament is a lifetime experience for them; they had the possibility to meet new friends and people from all around the world. They got to know new cultures and they started to compare the situation and problems in Uganda with that of other countries.

"...It is through this football for hope, that we have learned at least each form each and every country, there is a problem. Not only in Uganda, we've learned that everyone has got a problem and every problem has got a solution..." (participant 1)

The participants acknowledged that they were learning about the cultures and countries. It was also clear for them that this tournament was different from the others. "This is different because it is not just about the football...Football is not everything in this tournament" (participant 2). Participant 3 mentioned, that "this tournament is all about fair play, make friends, that's all. It is a fair play tournament." Fair play was also 
associated with living in peace. The talking with the other teams from different countries made them aware of their own situation and other problems existing around world. The tournament was giving them confidence for resolving problems.

\section{Exposure, education and discipline}

According to the participants playing football enables them to be exposed. This was explained as the situation where they are exposed outside of the country when playing in big tournaments (like Gothia Cup) and through these events they can explain better their talent. One participant wants to become a professional football player and sees TKL as one of the best academies in Uganda. Football can mean everything to them and it is used to express themselves. Other one is aware of the fact that he will not play the football forever, "...they tell [TKL] us how someone cannot play football forever" (participant 1). They also play football because through it they can get the scholarship paid. The school then pays the scholarship for them because they play football in the school team. The family would not be able to pay the school fees. Football is mentioned to be the hobby and also a tool that brings people together and teaches teamwork and discipline. During the football games the youth can experience happiness and also disappointment. These are among the main reasons mentioned when talking about why the participants play football.

\section{Connection to the situation in Uganda}

Playing football is seen as a possibility how to be kept out of the troubles of everyday life, "...football has helped me not to join the bad groups, like, there are some bad groups who smokes, take drugs like alcohol..." (participant 3). This activity is one of few that are offered to the children in Kampala and other parts of the country. All three participants express they love with their country, but they are aware about the problems like e.g. corruption and poverty. They mention that football can teach you how to act properly and send you to school. According to one opinion footballers in the school are generally seen by other schoolmates in Uganda as lazy, untrustworthy and being their own bosses. One participant on the other side uses football to show that he is able to do both - go to school and play too.

\section{DISCUSSION AND CONCLUSIONS}

Football plays a very important role in the lives of the participants. They see it as tool to get access to the education and all the other features already mentioned above. The indirect answers to the research questions are mentioned in the previous paragraphs. It is necessary to mention that all the answers are generally very positive and the youth see the football very positively. Based on the findings above the researcher sees the danger that could be the overestimated importance of football and the belief that the professional career is waiting for each participant. It is possible to conclude that football enhance the personal development of the interviewed youth because it is bringing many new possibilities into their lives. The education is here in the mentioned case very much linked to the football.

It was very hard to get from the teenagers any critical answers about the role of football in their lives. The researcher is also very much aware of the fact the she is the young white female doing the research with black Ugandan youth in Africa. That is why she wanted to spend with the youth as much time as possible and planned also further research stay in Uganda. But anyway all the answers mentioned here can be biased due to this situation of power relations. The researcher is aware of the fact that these are just very preliminary results and further analysis will follow. 


\section{REFERENCES}

1. AUBREY B. Managing your aspirations: developing personal enterprise in the global workplace. Singapore: McGraw - Hill Education; 2010.

2. DARNELL SC. Playing with race: right to play and the production of whiteness in "development through sport". Sport in Society. 2007; 10(4):560-579.

3. HAYHURST LMC. The power to shape policy: charting sport for development and peace policy discourses. International Journal of Sport Policy. 2009; 1(2):203-227.

4. HENDL J. Kvalitativní výzkum: základní teorie, metody a aplikace. Praha: Portál; 2008.

5. KOHOUTEK R. Základy psychologie osobnosti. Brno: Cerm; 2000.

6. LEVERMORE R, BEACOM A. Sport and international development. London: Palgrave MacMillan; 2009.

7. LEVERMORE R. Evaluatin sport-for-development: approaches and critical issues. Progress in Development Studies. 2011; 11(4):339-353.

8. NICHOLLS S, GILES AR, SETHAN C. Perpetuating the 'lack of evidence' discourse in sport for development: Privileged voices, unheard stories and subjugated knowledge. International Review for the Sociology of Sport. 2011; 46(3):249-264.

9. PUNCH KF. Introduction to social research. London: Sage Publications; 2005.

10. SMÉKAL V. Pozvání do psychologie osobnosti. Člověk v zrcadle vědomí a jednání. Brno: Barrister \& Principal; 2004. 